(RESEARCH ARTICLE)

\title{
Amino acid profile, microbiological and farinographic properties of African locust bean pulp flour
}

\author{
Akubor Peter Isah \\ Department of Food Science and Technology, Federal University Wukari, Taraba State, Nigeria.
}

Publication history: Received on 13 October 2017; revised on 15 November 2017; accepted on 05 December 2017

https://doi.org/10.30574/gscbps.2017.1.3.0046

\begin{abstract}
Flour was prepared from African locust bean (Parkia biglobosa) fruit pulp and evaluated for the amino acid composition, microbiological and farinographic characteristics. The locust bean pulp flour contained $4.8 \%$ total crude protein and 17 amino acids. The major amino acids in the locust bean pulp flour protein were glutamin acid, aspartate acid, leucine and arginine. Leucine, lysine and phenylalanine were the major essential amino acids. Methionine had the lowest concentration and tryptophan was the second limiting amino acid in the locust bean pulp flour protein. The bacteria isolated from the pulp included Bacillus cereus, Leuconostoc and Streptococcus species.The yeasts and moulds found in the pulp were Rhizopus and Saccharomyces species. Colifoms were not detected in the pulp. The total bacteria count was $4.6 \times 10^{4} \mathrm{cfu} / \mathrm{g}$. The Bacillus cereus, Streptococcus aureus, yeasts and moulds counts were $0.5 \times 10^{4}, 3.2 \times 10^{4}$ and $2.4 \mathrm{x}$ $10^{4} \mathrm{cfu} / \mathrm{g}$, respectively. The farinographic water absorptions were $60 \%$ and $68 \%$ for wheat flour and the African locust bean pulp flour, respectively. The water absorption increased with increase in the level of locust bean pulp flour in the blends. The dough development time was higher for the locust bean pulp flour (3.0 min) than for wheat flour (1.7 min).The dough development time increased steadily with increase in the level of African locust bean pulp flour addition. The mixing tolerance index decreased from 79 BU (Brabender unit) in wheat flour to 42 BU in the blend containing $90 \%$ locust bean pulp flour. The dough stability also decreased with increased level of the locust bean pulp flour in the blends. African locust bean pulp flour and wheat flour blends have the potential for use in baked food products.
\end{abstract}

Keywords: Locust bean; Amino acid; Microbial; Farinograph; Flour; Rheology

\section{Introduction}

African locust bean (Parkia biglobosa) tree grows widely in many parts of the Sahel, particularly, the drier parts of West Africa [1]. In Nigeria, the tree grows in the wild throughout the savanna from Guinea through Sudan to Sahel [2]. The tree produces 25-52 kg pods [2]. In Northern Nigeria alone, about 200,000 tons of locust bean pods are produced yearly [2]. A mature locust bean pod contains yellow dry and powdery pulp in which dark brown seeds are embedded. The pulp is rich in carbohydrates, minerals, vitamins and essential phytochemicals such as flavonoids, carotenoids, polyphenols, saponins etc [3-4]. The pulp is usually licked for its sweet taste but only to a small extent [4]. The pulp is usually washed away when the seeds are processed into condiment called dawadawa or iru. There is growing interest in the utilization of locust bean pulp due to its nutraceutical potential [4] and this has led to extensive studies on the pulp [5]. The chemical composition and functional properties of locust bean pulp flour have been determined [1,4]. The effects of $\mathrm{pH}$ and $\mathrm{NaCl}$ concentration on the functional properties of the pulp flour were recently reported by Akubor and Adedeji [6]. The presence of flavonoids, carotenoids and vitamin $C$ in the locust bean pulp would exert health

\footnotetext{
${ }^{*}$ Corresponding author

E-mail address: akuborpeter@ gmail.com

Copyright (C) 2017 Author(s) retain the copyright of this article. This article is published under the terms of the Creative Commons Attribution Liscense 4.0.
} 
promoting effect in addition to those of the dietary fiber [3,7]. Akubor [8] reported the changes in the physical, chemical, sensory and microbiological qualities of syrup and jam prepared from locust bean pulp during storage.

Information on the microbiological safety and baking properties of locust bean pulp flour are lacking in the literature. Locust bean pulp, like other fruit pulps has the potential for supporting the growth of both pathogens and spoilage microorganisms [9]. The locust bean pods are picked after they have fallen from the tree to the ground from where they are packed in baskets for the processing seeds. The microorganisms can be introduced into the pods directly from the handlers, the environment, during transportation and storage [10]. Ikuomola and Eniola [11] reported that several factors including water availability, $\mathrm{pH}$, temperature etc. encourage or limit the growth of microorganisms in foods .Consumer preference for safe and quality food product is increasing. Microbial food safety is an increasing public health concern worldwide [12]. Microbial quality is the degree of acceptability of the total number of microbes present in a given food [13]. There is little or nothing in the literature on the microbial safety of locust bean pulp. Therefore, microbiological analysis needs to be carried out to determine the safety of the pulp. The prevention of microbial spoilage is an important element of storage stability.

Wheat flour quality is assessed by physical and chemical tests as well as baking tests. The instruments that are used to test gluten quality include Siman extensimer, Chopin alveograph, Brabender extensograph and Brabender farinograph [14]. The first three measure wheat gluten protein resistance to stretch without breaking (extensibility) [14]. Farinograph is the most widely used to understand the rheological behavior during dough mixing [15]. The farinograph records in graphical format a complex rheological changes taking place in wheat dough during mixing and also facilitates the accurate calculation of the water required to achieve a given consistency [15]. Farinograph is used to evaluate various rheological parameters such as ability of flour to absorb water ,time it takes the dough to develop, strength of dough , dough stability etc. [16].

Therefore, the objective of the present study was to determine the amino acid composition, microbiological and farinographic properties of locust bean pulp flour.

\section{Material and methods}

Mature and ripe African locust bean (Parkia biglobosa) fruit pods were plucked from locust bean trees in a local farm in Ugwaka -Ollah Township, Kogi State, Nigeria. Commercial wheat flour was purchased from a local shop in Idah Township, sieved through 60 mesh sieve $(0.05 \mathrm{~mm}$ ) (British standard) and stored in high density polyethylene bag in a refrigerator prior $\left(10^{\circ} \mathrm{C}\right)$ to use. The nutrient agar (Merk), potato dextrose agar (Oxoid) etc. were purchased from a chemical store in Idah Township.

\subsection{Determination of amino acid composition}

The total crude protein content (Kjeldahl method) and the amino acid composition of the African locust bean pulp flour were determined using the method described by the AOAC [17] methods. Five gramme of the sample was dried until the weight became constant, defatted in Soxhlet apparatus using hexane, hydrolyzed, concentrated in a rotary evaporator. Then, the sample was placed into the Technicon sequential Amino acid analyzer Union Carbide Corp, New York, NY (TSM) for the amino acid analysis. Amino acid values were calculated from the chromatograph as: Value of amino acid in locust bean pulp flour (g/100 g protein)/FAO amino acid reference value x 100.

\subsection{Evaluation of microbiological properties}

The bacteria, yeast and mould counts were determined by the methods described by Ray and Bhunia [18]. One gram of the flour was mixed thoroughly with $9 \mathrm{ml}$ of $0.1 \% \mathrm{w} / \mathrm{v}$ peptone water $(\mathrm{pH} 7.2)$. One milliliter of the dilution $\left(10^{-1}-10^{-}\right.$ ${ }^{5}$ ) was plated with on nutrient agar (Merek) for bacterial count and potato dextrose agar (Oxoid) for mould and yeast counts using the pour plate technique. The plates were incubated at $37^{\circ} \mathrm{C}$ and $30^{\circ} \mathrm{C}$, respectively for $24 \mathrm{~h}$ for bacteria, yeast and mould counts. Counts of microorganisms carried out using colony counter (Gallenkamp, UK) and the results were expressed as colony forming unit (cfu/g).

\subsubsection{Identification of isolates}

Each of the cultured plates was sub cultured and purer cultures were obtained. The bacterial isolates were identified by their cultural and morphological tests which included gram staining reactions, biochemical tests and oxidative / fermentative utilization of sugars [19]. The yeasts and moulds were identified based their cultural and morphological characteristic [19]. The biochemical analyses were catalase, coagulase, indole production tests and sugar utilization test. For the cultural and morphological identification, $0.5 \mathrm{~g}$ of the pure colonies was smeared on a slide after which 
methylene blue was added for staining [19]. After staining, the slide was mounted on a microscope for identification of microorganisms.

\subsubsection{Bacillus and Staphylococcus spp counts}

For the Bacillus counts, a 10-fold dilution was prepared from flour sample and plated unto a nutrient agar. Following incubation for 24- $48 \mathrm{~h}$, a confirmatory staining procedure was made on suspected colonies [18]. Colonies confirmed were counted using colony counter and the results reported as $\mathrm{cfu} / \mathrm{g}$. For the Staphylococcus counts, the flour was mixed with water from which a 10-fold dilution series was prepared. Aliquots from range of dilutions were transferred into a mixture of nutrient agar and sodium chloride and the plates were incubated under aerobic condition at $35^{\circ} \mathrm{C}[18]$. The number of colonies of Staphylococcus spp were counted using colony counter and the level of the pathogen in the flour was expressed as $\mathrm{cfu} / \mathrm{g}$.

\subsection{Evaluation of the farinographic properties}

The farinographic characteristics of the flour were determined as described by the AOAC [17] method using Brabender farinogragh (Brabender, Germany) was used for the study. From the farinogragh, the water absorption, time it takes the dough to develop, mixing tolerance index, stability of dough and the dough softening determined.

\subsection{Experimental design and statistical analysis}

The experiments were carried out in completely randomized design in three replications. The data generated were subjected to analysis of variance (ANOVA) using Statistical Package for Social Sciences (SPSS) version 17, 2007). Means where significantly different were separated using Duncan Multiple range test (DMRT).

\section{Results and discussion}

\subsection{Amino acid composition}

Table 1 Amino acid composition of African locust bean pulp flour and chemical scores of the essential amino acids

\begin{tabular}{|c|c|c|c|}
\hline Amino acid (g/100g protein) & FAO Reference value $x$ & Locust bean pulp flour & Chemical score (\%) xx \\
\hline Lysine & 4.20 & 3.30 & 78.57 \\
\hline Histidine & & 1.90 & \\
\hline Threonine & 2.80 & 2.29 & 81.79 \\
\hline Tryptohan & 1.40 & 0.70 & $50.00^{\mathrm{b}}$ \\
\hline Serine & & 3.30 & \\
\hline Aspartate acid & & 6.50 & \\
\hline Glutamin acid & & 11.0 & \\
\hline Glycine & & 3.98 & \\
\hline Proline & & 2.30 & \\
\hline Alanine & & 2.60 & \\
\hline Cysteine & 2.00 & 1.50 & 75.00 \\
\hline Isoluecine & 4.20 & 3.10 & 73.80 \\
\hline Phenylalanine & 2.60 & 3.29 & 126.54 \\
\hline Tyrosine & 2.50 & 1.81 & 72.40 \\
\hline Valine & 4.20 & 2.60 & 61.90 \\
\hline Leucine & 4.20 & 6.02 & 143.33 \\
\hline Methionine & 2.20 & 0.47 & $21.36^{a}$ \\
\hline Arginine & & 4.00 & \\
\hline Protein(N x 6.25) & & 4.80 & \\
\hline
\end{tabular}

The amino acid composition of African locust bean pulp flour is presented in Table 1 . The pulp flour contained $4.8 \%$ total protein and 17 amino acids. The major amino acids in the locust bean pulp flour protein were glutamin acid, aspartic acid, leucine and arginine. All the amino acids were present in varying amounts with leucine, lysine and phenylalanine constituting the major essential amino acids. Of particular interest was the high level of lysine, leucine and threonine in the pulp. Lysine and threonine are present at very low concentrations in wheat, rice, cassava and diets containing maize that are commonly consumed in developing countries including Nigeria [20]. The presence of high 
levels of these amino acids makes locust bean pulp flour a good supplement for these staple food stuffs [21]. The content of the sulphur amino acid cysteine $(1.5 \mathrm{~g} / 100 \mathrm{~g}$ ) was comparable to the FAO reference value of $2.0 \mathrm{~g} / 100 \mathrm{~g}$ [16]. However, methionine was the first limiting amino acid and tryptophan the second limiting amino acid in the locust bean pulp flour protein. Similar amino acid pattern was reported for the locust bean pulp seeds [22]. The role of amino acids in the normal functioning of the human body cannot be over stressed. Leucine and histidine which are substantial in the African locust bean pulp flour are reported to enhance the growth of infants and young children [14]. Histidine plays an important role in the catalytic activity of many enzymes [16]. The threonine, serine, tyrosine contain polar hydroxyl groups which enable them to participate in hydrogen bonding [20]. Alanine is suited for diffusing from muscle cells into the blood to be transported by the blood to the liver for utilization in gluconeogenesis. Valine, leucine and isoleucine are also utilized for the synthesis of substrates for gluconeogenesis [23]. For ketogenesis, phenylalanine is useful for the synthesis of melanin, a pigment that contributes to the color of the eye, hair and skin. Tryptophan is used for the synthesis of serotonin. Aspartate and glutamate transport ammonia to the liver and kidney for the production of urea.

\subsection{Microbiological properties}

The cultural, morphological and biochemical characteristics of bacteria, yeasts and moulds isolated from the locust bean pulp flour are presented in Tables 2-4. The bacteria isolated from the pulp include Bacillus cereus, Leuconostoc and Streptococcus species (Tables 2 and 3). The yeasts and moulds found in the pulp were Rhizopus and Saccharomyces species (Table 4). Colifoms were not detected in the pulp. Arora [19] reported that similar spectra of microorganisms as surface flora of fruits and vegetables. Uzugegbu and Emifonige [24] also made similar observation on local fruits and vegetables in Nigeria.

Table 2 Cultural, morphological and biochemical characteristics of bacteria isolates from locust bean pulp flour

\begin{tabular}{|c|c|c|c|}
\hline \multicolumn{2}{|l|}{ Test } & \multicolumn{2}{|l|}{ Results } \\
\hline Cultural & $\begin{array}{l}\text { Large crenated creamy } \\
\text { colonies with raised edges }\end{array}$ & $\begin{array}{l}\text { Small round creamy } \\
\text { colonies }\end{array}$ & $\begin{array}{l}\text { Whitish raised round } \\
\text { colonies }\end{array}$ \\
\hline Morphological & Rods in chain & Cocci in pairs & Cocci in clusters \\
\hline \multicolumn{4}{|l|}{ Biochemical reaction } \\
\hline Grams reaction & + & + & + \\
\hline Catalase test & + & - & + \\
\hline Coagulase test & - & - & + \\
\hline Indole test & - & - & - \\
\hline Suspected organism & Bacillus spp & Leuconostoc & Staphylococcus spp \\
\hline
\end{tabular}

Table 3 Sugar utilization by microorganisms isolated from locust bean pulp flour

\begin{tabular}{llll}
\hline Sugar & Pulp & Samples \\
\hline \multirow{2}{*}{ Lactose } & 1 & 2 & 3 \\
Glucose & A & A & A \\
Fructose & A & A & A \\
Maltose & A & A & A \\
Suspected organism & Lactobacillus spp & Lactobacillus spp & Lactobacillus spp \\
\hline & \multicolumn{2}{c}{ A= Acid production. }
\end{tabular}

The counts for the microorganisms in locust bean pulp flour are shown in Table 5 . The total bacteria count was $4.6 \mathrm{x}$ $10^{4} \mathrm{cfu} / \mathrm{g}$. The Bacillus cereus, Streptococcus aureus, yeasts and moulds counts were $0.5 \times 10^{4}, 3.2 \times 10^{4}$ and $2.4 \mathrm{x}$ $10^{4} \mathrm{cfu} / \mathrm{g}$, respectively. These values are considered high when compared to the recommended standard counts of $10 \mathrm{x}$ $10^{5}$ to $10 \times 10^{4}[25]$ for foods. 
However, when compared to the other standards, the levels of microorganisms in the locust bean pulp flour were within the tolerable levels [25]. The international microbiological standards recommended limits for bacterial contamination of foods were in the range of $10^{1}$ to $10^{2} \mathrm{cfu} / \mathrm{g}$ for coliform organisms and less than $10^{5} \mathrm{cfu} / \mathrm{g}$ of food for total plate count [25]. At levels of $10^{4} \mathrm{cfu} / \mathrm{g}$ or above, production of heat stable toxin may occur [26]. Some of the organisms isolated from locust bean pulp flour such as Staphylococcus aureus and Bacillus cereus are pathogenic while others are not [27]. If the count of Bacillus reaches high level in food, it produces toxin [26]. Most of the microorganisms in locust bean pulp flour are found on body surfaces or soil [28]. The high level of contamination of locust bean pulp flour was probably due to poor storage and handling practices [29].

Table 4 Cultural and morphological characteristics of yeasts and moulds isolated from locust bean pulp flour

\begin{tabular}{lll}
\hline Cultural characteristics & Morphological characteristics & Suspected organism \\
\hline Black round colony & Non syptate hayphae & Rhizopus spp \\
Moist creamy colony & Round cells with budding & Saccharomyces spp \\
\hline
\end{tabular}

The other sources of contamination of the pulp might have included the soil on which the fruit pods were produced and harvested [30]. Also, the harvested pods were packed in jute bags stored on the floor of the laboratory, which was probably charged with pores of microorganisms. Storage of the pods for a length of time under these conditions at high ambient temperature probably encouraged the proliferation of bacteria [10]. The type of fertilizer used to improve the soil quality and yield as well as the environment were sources of contamination of garden egg [31]. The Staphylococcus aureus is generally found in the skin, nose, throat, palms, hairs and mucus membrane of humans [32].The presence of Staphylococcus aureus in locust bean pulp flour is of health significance they are capable of causing gastrointestinal problems especially to consumer who eat the raw pulp.

Fungi are well spread in nature, being found as spores on fruits and vegetables [32]. The presence of penicillum species on LBPF was in agreement with the report of Adebolu and Ifsan [31] that isolated Aspergillus and Penicillium species from vegetables used in preparing salad that were bought from various food shops in Akure, Ondo State, Nigeria. The presence of toxigenic penicillium species inlocust bean pulp flour should be viewed with concern. Inyang et al. [30] reported that foods contaminated with Penicillium spp are capable of causing liver cancer when consumed. Apergillus and Penicillium have been reported to produce aflatoxins which have carcinogenic, hemorrhagic, heptaotoxic, neurotoxic and uterotrophic properties [30].

Table 5 Microbial counts of locust bean pulp flour

\begin{tabular}{ll}
\hline Type of microorganism & Count $\mathbf{c f u} / \mathbf{g})$ \\
\hline Bacteria & $4.6 \times 10^{4}$ \\
Bacillus cereus & $0.5 \times 10^{4}$ \\
Staphylococcus aureus & $3.2 \times 10^{4}$ \\
Yeasts and moulds & $2.4 \times 10^{4}$ \\
\hline \multicolumn{2}{c}{ Values are means of three replications. }
\end{tabular}

\subsection{Farinographic properties}

The farinographic characteristics of the locust bean pulp flour, wheat flour and their blends are shown in Table 6. The farinographic water absorptions were $60 \%$ and $68 \%$ for wheat flour and locust bean pulp flour, respectively. The water absorption increased with increase in the level of locust bean pulp flour in the blends probably due to addition effect $[16,32]$. The water absorption increased from $60 \%$ in the wheat flour to $67.5 \%$ for the blend containing $90 \%$ locust bean pulp flour. This means that at fixed water absorption, the locust bean pulp/ wheat flour blend showed maximum consistency above the 500 BU (Brabender units) line and in such cases, water has to be increased to center the farinograph curve on 500 BU. Similar results were reported for plantain/wheat flour blends [33]. 
Table 6 Farinographic characteristics of locust bean pulp flour (LBPF), wheat flour (WF) and the blends

\begin{tabular}{|c|c|c|c|c|c|}
\hline LBPF:WF & $\begin{array}{l}\text { Water } \\
\text { absorption } \\
(\%)\end{array}$ & $\begin{array}{l}\text { Dough } \\
\text { development } \\
\text { time(min) }\end{array}$ & $\begin{array}{l}\text { Mixing } \\
\text { tolerance } \\
\text { index (BU) }\end{array}$ & $\begin{array}{l}\text { Dough } \\
\text { stability (min) }\end{array}$ & $\begin{array}{l}\text { Dough } \\
\text { softening (BU) }\end{array}$ \\
\hline 100:0 & $68^{a}$ & $3.0^{\mathrm{b}}$ & $20^{\mathrm{k}}$ & $1.5 \mathrm{c}$ & $60^{\mathrm{a}}$ \\
\hline $0: 100$ & $60^{f}$ & $1.7^{\mathrm{c}}$ & $79^{a}$ & $3.0 \mathrm{a}$ & $116^{\mathrm{i}}$ \\
\hline $10: 90$ & $61^{\mathrm{e}}$ & $2.0^{c}$ & $78^{b}$ & $2.9^{a}$ & $117^{\mathrm{h}}$ \\
\hline $20: 80$ & $61.8^{\mathrm{de}}$ & $2.1^{\mathrm{c}}$ & $75^{c}$ & $2.8^{\mathrm{a}}$ & $119 \mathrm{~g}$ \\
\hline $30: 70$ & $62.5^{\mathrm{d}}$ & $2.2^{\mathrm{c}}$ & $74^{d}$ & $2.6^{\mathrm{a}}$ & $120.5^{f}$ \\
\hline $40: 60$ & $63^{d}$ & $3.0^{\mathrm{b}}$ & $71^{\mathrm{e}}$ & $2.5^{\mathrm{ab}}$ & $122^{\mathrm{e}}$ \\
\hline $50 ; 50$ & $63.5^{\mathrm{cd}}$ & $3.1^{b}$ & $70^{f}$ & $2.3^{\mathrm{b}}$ & $131.0^{\mathrm{d}}$ \\
\hline $60: 40$ & $64^{c}$ & $3.4^{\mathrm{ab}}$ & $68^{g}$ & $2.1^{\mathrm{b}}$ & $132^{c}$ \\
\hline $70: 30$ & $64.75^{b c}$ & $3.5^{\mathrm{a}}$ & $67^{\mathrm{h}}$ & $2.0^{\mathrm{b}}$ & $133^{b}$ \\
\hline $80: 20$ & $64.9 \mathrm{bc}$ & $3.6^{\mathrm{a}}$ & $65^{\mathrm{i}}$ & $1.8^{\mathrm{b}}$ & $133.5^{b}$ \\
\hline $90: 10$ & $65^{b}$ & $3.7^{\mathrm{a}}$ & $63^{j}$ & $1.6 b^{c}$ & $132^{\mathrm{b}}$ \\
\hline
\end{tabular}

Values are means of three replications. Means within a column with the same superscript were not significantly different (p>0.05)

The dough development time, which is defined as the time to the nearest half minute from the first addition of water to the development of maximum consistency of the dough was higher for the locust bean pulp flour (3.0 min) than for wheat flour (1.7 min).The dough development time increased steadily with increase in the level of African locust bean pulp flour addition. The mixing tolerance index defined as the difference in the BU from the top of the farinograph at the peak to the top of the curve measured at $5 \mathrm{~min}$ after the peak is reached decreased with increase in the level of African locust bean pulp flour in the blends. The mixing tolerance index decreased from79BU in wheat flour to $42 \mathrm{BU}$ in the blend containing 90\% African locust bean pulp flour. The dough stability also decreased with increased level of African locust bean pulp flour in the blends. Bamidele et al. [34] reported a continuous increase in dough stability with increase in the level of plantain flour in the blends. This was contrary to the results of the present study. The differences can be attributed to the variation in the chemical nature of the flours [14]. The longer the stability, the better the dough from plantain/ wheat flour blends [34]. The dough softening increased substantially with increase in the level LBPF in the blends. Bemidele et al. [34] made similar observations for wheat flour and breadfruit flour blends.

\section{Conclusion}

African locust bean pulp flour contained 17 essential and non-essential amino acids with methionine and tryptophan as the limiting amino acids. The raw African locust bean pulp flour is microbiological safe for human consumption. The blends of African locust bean pulp flour and wheat flour have the potential for use in baked food products.

\section{Compliance with ethical standards}

\section{Acknowledgments}

The author acknowledges the contribution of the staff of the Department of Food Science and Technology, The Federal Polytechnic, Idah, Kogi State, for the analysis of samples.

\section{Disclosure of conflict of interest}

The author has declared no conflict of interest in the present study. 


\section{References}

[1] Akoma O, Onuoha SA, Akoma AO and Ozigis AA. (2001). Physicochemical attributes of wine produced from the yellow pulp of the Parkia biglobosa using traditional juice extraction technique. Nigerian Food Journal, 19, 76-79.

[2] Addy EOU, Salami CI, Igboeli C and Emawa HS. (1995). Effect of processing on nutrient composition and antinutirive substances of African locust bean (Parkia folicodea) and baaoba (Adansonia digitata) seed. Plant Foods Human Nutrition, 48(1), 13-17.

[3] Gernah DI, Atulagbe MO and Echogwo CC. (2007). Nutritional composition of the African locust bean pulp. Nigerian Food Joiurnal, 25(1), 190-196.

[4] Akubor PI. (2016).Chemical composition and functional properties of locust bean pulp flour and wheat flours. FUW Trends in Science and Technology Journal 1(1), 248-253.

[5] Musa S, Yusufu YA, Koleola AA and Akoma A. (2005). Chemical composition and nutritional characteristics of kirbwang (A traditional fermented locust bean pulp snack). Nigerian Food Journal, 23, 8-12.

[6] Akubor PI and Adedeji EO. (2016). Effect of pH and sodium chloride concentration on the functional properties of locust bean pulp flour. FUW Trends in Science and Technology Journal, 1(2), 344-347.

[7] Ajaiyeoba EO. (2002). Phytochemical and antibacterial properties of Parkia bicolor leaf extracts. African Journal of Biomedical Research, 3, 125-127.

[8] Akubor PI. (2017). Physicochemical, sensory and microbiological properties of syrup and jam prepared from locus bean pulp in storage. Asian Journal of Biotechnology and Bioresource Technology, 1(3), 1-8.

[9] Obadina AO and Ogundimu AA. (2011). Microbial contamination of selected herbal and dietary supplements in typical tropical markets. Nigerian Food Journal, 29(1), 41-45.

[10] Odom, TC, Udensi EA and Nwaneke EC. (2012). Microbiological qualities of hawked retted cassava fufu in Aba metropolis of Abia State, Nigeria. Nigerian Food Journal, 30(1), 53-58.

[11] Ikuomola DS and Eniola KI. (2010). Microbiological quality and public health risk associated with beske retailed in Ikeji- arakeji, Osun State, Nigeria. Nigerian Journal of Microbiology, 24(1), 2114-2118.

[12] ICMSF. (2009). Microorganisms in Food: sampling for microbiological analysis. Principles and specific applications. $2^{\text {nd }}$ Ed, Blackwell Scientific Publications, UK, 10-138.

[13] Akhibgemidu W, Muas A and Kurforiji O. (2015). Assessment of the microbial qualities of noodles the accompanying seasonings. Nigerian Food Journal, 33, 48-53.

[14] Okaka JC. (1997). Cereals and legumes: Storage and processing Technology. Dato and Microsystem publishers, Ogui, Enugu State, Nigeria, 123-387.

[15] Singh M and Khartkar BS. (2005). Structural and functional properties of wheat storage proteins. A review. A review in Food Science and Technology, 43, 1-7.

[16] Enwere NJ. (1998). Food of plant origin. Afro-Orbit Publications Ltd., Nsukka, Nigeria, 135-148

[17] AOAC. (2010). Official Methods of Analysis. 20th Ed. DC Association of Official Analytical Chemists, Washington, 278-368.

[18] Ray B and Bhania, AK. (2007). Fundamentals of Food Microoganisms. 4th Ed, CRC Press, USA, $492-541$.

[19] Arora, DR. (2004). Textbook of Microbiology. CBS Publishers and Distributors, New York, 578-690.

[20] Onimawo IA and Akubor PI. (2012). Food chemistry (Integrated approach with biochemical Background). 2 ${ }^{\text {nd }}$ Ed. Joytal Printing Press, Agbowo, Ibadan, Nigeria, 124-245.

[21] Owoyele JA, Shok A and Olabemoro T. (1989). Some chemical constituents of the fruit pulp of Parkia clappertoniana as a potential industrial raw material. Savanna, 9(2), 24- 27.

[22] Olajide JD and Ade-omowaye BIO. (1999). Some physical properties of locust bean seed. Journal of Agricultural Engineering Research, 74, 213-215.

[23] FAO (1992). Manuals on food quality control: Foods and Nutrition paper No 14/14 of the Food and Agriculture Organization of the United Nations, Rome, 201-298. 
[24] Uzugebu JO and Emifoniye AJ. (1984). Postharvest fungal spoilage of some Nigeria fruits and vegetables. Nigerian Food Journal, 12,153-155.

[25] International Committee on Microbiological Specifications for foods (ICMSF). (2006). Microbiology in foods 5: Microbiological specifications of food pathogens. Clays Ltd. St Ives plc, Bungay Suffolk.UK, 123-245.

[26] World Health Organization. (2008). Exposure assessment of microbiological health in foods. Guidelines. Microbiological risk assessment 7. WHO, Rome, Italy, 213 -365.

[27] Offia -olua BI and Edide RO. (2013). Chemical, microbial and sensory properties of candied-pineapple and cherry cakes. Nigerian Food Journal, 31(1), 33-39.

[28] Antai SP and Ibrahim MH. (1988). Microoganisms associated with African locust bean (Parkia filicoidea) fermentation for dawadawa production. Journal of Applied Bacteriology, 61, 145-148.

[29] Ogbulie TE, Nsofor, CA, Nze FC (2014). Bacteria species associated with ugba (Pentachlethra macrophylla) produced traditionally and in the laboratory and the effect of fermentation on product of oligosaccharide hydrolysis. Nigerian Food Journal, 32(2), 81-91.

[30] Inyang CU, Igyor MA and Uma EN (2005). Bacterial quality of smoked meat product (suya). Nigeria Food Journal, 25, 2309- 242.

[31] Adebolu BA and Ifesan CN. (2001). Bacteriological quality of vegetables used in salad. Nigerian Journal of Microbiology, 5, 81-85.

[32] Ogundipe FO, Bamidele FA, Adebayo-Oyetoro, AO, Oundipe 00 and Tajudeen OK. (2012). Incidence of bacteria with potential public health implication in raw Lycopersicon esculentum (tomato) sold in Lagos State, Nigeria. Nigerian Food Journal, 30(2), 106-113.

[33] Ogazi PO (1985). The rheological properties of plantain flour as composite with wheat flour, Nigerian Food Journal, 3, 190-193.

[34] Bamidele IA, Cardoso AO and Olaofe O. (1990). Rheology and the baking potential of wheat plantain composite flour. Journal of Science Food Agriculture, 51, 421-424.

\section{How to cite this article}

Akubor PI. (2017). Amino acid profile, microbiological and farinographic properties of African locust bean pulp flour. GSC Biological and Pharmaceutical Sciences, 1(3), 29-36. 